\title{
Sistem Pendukung Keputusan untuk Seleksi Karyawan Baru dengan Metode Simple Additive Weighting (Saw) Berbasis Web
}

\author{
Enggar Novianto (1300018002) ${ }^{a, 1}$, , Sri Winiarti (0516127501) ${ }^{b, 2}$ \\ a Program Studi Teknik Informatika Universitas Ahmad Dahlan \\ Jl. Prof. Dr.Soepomo, Janturan, Yogyakarta 55164, Indonesia \\ ${ }^{1}$ engggar1300018002@webmail.uad.ac.id ; ${ }^{2}$ sri.winiarti@tif.uad.ac.id
}

\section{ABSTRAK}

Seiring dengan semakin berkembangnya sumber daya manusia baik dalam hal kuantitas maupun kualitas, maka semakin besar pula tuntutan bagi manajemen sumber daya manusia untuk melakukan pengelolaan secara komprehensif dan berkesinambungan. Penerapan tenaga kerja yang tinggi menjadi masalah tersediri ketika posisi yang ditawarkan relatif banyak. Penerimaan karyawan dilakukan melalui sistem ujian tertulis, kemudian dilakukan perhitungan secara manual. Cara penilaian seperti itu memakan waktu 1 bulan dan rentan kesalahan. Oleh sebab itu perlu adanya suatu sistem yang dapat mempermudah bagian HRD dalam menentuakan keputusannya dalam memilih kandidat-kandidat calon karyawan yang sesuai kriteria.

Dalam penelitian ini menggunakan metode pengumpulan data dengan pengamatan informasi lowongan pekerjaan, tata cara pelamar mengirimkan berkas melalui website, study literature, wawancara dengan bagian HRD. Tahap pengembangan aplikasi ini meliputi perancangan sistem menggunakan DAD,ERD, mapping table, alur keputusan, dan metode yang digunakan adalah metode Simple Additive Weighting dan pengujian menggunakan black box test dan pengujian perhitungan algoritma Simple Additive Weighting.

Dari penelitian yang dilakukan menghasilkan sebuah perangkat lunak sistem pendukung keputusan untuk seleksi karyawan baru dengan metode Simple Additive Weighting berbasis web dengan dapat memberikan informasi hasil penilaian yang dilakukan kepada setiap calon karyawan yang akan di seleksi dan hasil pengujian dari sistem ini bahwa hasil pengujian dengan menggunakan black box test dan hasil pengujian dengan menggunakan perhitungan perhitungan algoritma SAW terdapat kesamaan atau valid $100 \%$.

Ciptaan disebarluaskan di bawah lisensi CC-BY-SA.

Kata kunci: Metode SAW, Seleksi Karyawan, Sistem Pendukung Keputusan

\section{Pendahuluan}

Seiring dengan semakin berkembangnya sumber daya manusia baik dalam hal kuantittas maupun kualitas, maka semakin besar pula tuntutan bagi manajemen sumber daya manusia untuk melakukan pengelolaan secara komprehensif dan berkesinambungan. Salah satu bagian penting dalam pengelolaan dan perkembangan sumber daya manusia adalah sistem dalam proses penyeleksian penerimaan calon karyawan yang bertujuan untuk mengisi jabatan yang kosong dalam suatu perusahaan dengan yang paling sesuai.

Penerimaan karyawan dilakukan melalui sistem ujian tertulis, kemudian dilakukan perhitungan secara konvensional. Cara penilaian seperti ini memakan waktu yang lama dan rentan kesalahan. Apalagi jika banyaknya pelamar yang memasukkan lamaran. Selain itu, proses dan hasil penilaian 
hanya dapat dilihat oleh bagian personalia, manipulasi terhadap hasil ujian sangat memungkinkan untuk dilakukan.

Selama ini proses pengumuman informasi lowongan kerja yang di informasikan oleh pihak RS PKU Muhammadiyah Kota Yogyakarta melalui website www.rspkujogja.com, bahwa calon pelamar mengirimkan berkas persyaratan melalui kantor pos atau mengirimkan secara langsung yang ditujukan kepada bagian Human Resource Development (HRD). Model pengiriman berkas seperti tersebut menyulitkan calon pelamar dalam mengirimkan berkas yang ditujukan kepada bagian HRD, terutama bagi calon pelamar yang berasal dari luar daerah dan dapat menyebabkan berkas tersebut rusak ataupun hilang selama proses pengiriman.

Oleh sebab itu perlu adanya suatu sistem yang dapat mempermudah calon karyawan dalam melakukan proses pendaftaran yang bisa di akses oleh semua pelamar dari berbagai daerah dan mempermudah bagian HRD dalam menentukan keputusannya dalam memilih kandidat-kandidat calon karyawan yang memiliki kriteria yang baik.

Aplikasi yang akan dibangun menggunakan metode Simple Additive Weighting, karena metode tersebut menggunakan metode pembobotan dari setiap kriteria yang telah ditetapkan, sehingga akan lebih cepat dan efisien untuk menentukan calon karyawan yang akan diseleksi. Untuk itu aplikasi tersebut di bangun melalui penelitian ini dengan judul "Sistem Pendukung Keputusan Untuk Seleksi Karyawan Baru Dengan Metode Simple Additive Weighting (SAW) Berbasis Web".

\section{Landasan Teori}

Kajian terdahulu dalam melakukan penelitian ini menggunakan hasil jurnal yang diambil dari Jurnal Sisfotenika, yang membahas tentang proses penerimaan pegawai baru yaitu harus sesuai dengan kriteria yang telah ditentukan. Untuk membantu dalam menseleksi penentuan seseorang yang layak menjadi pegawai, maka dibutuhkan sebuah sistem pendukung keputusan.

Kajian penelitian kedua yang digunakan adalah pada Jurnal Informatika, yang membahas tentang perekrutan, penggajian dan absensi karyawan. Penelitian ini menggunakan metode Topsis untuk membantu proses perekretuan dan memilih calon pegawai yang sesuai dengan kualaifikasi, selain membantu proses perekrutan calon pegawai, penelitian ini juga dapat membantu perusahaan untuk menghitung gaji pegawai.

Dalam penelitian yang terdapat dalam jurnal Manajemen Indonesia yang membahas tentang proses perekrutan dan seleksi karyawan PT. Qwords Company, saat ini proses rekrutmen dan seleksi karyawannya masih menggunakan metode manual dan juga menggunakan kertas.

Berdasarkan penelitian yang terdapat dalam Jurnal Informatika Mulawarman. Penelitian ini menggunakan metode Technique for Order Preference by Similarity to Ideal Solution (TOPSIS) dan Fuzzy Multiple Criteria Decision Making (FMCDM) digunakan sebagai metode untuk memberikan penilaian calon karyawan yang akan diseleksi. Pada penelitian tersebut, penulis membangun sistem bagaimana menciptakan sistem untuk menentukan kriteria terhadap calon karyawan yang akan melamar, menyimpan data-data dari calon pelamar dan melakukan proses seleksi pada bagian yang dibutuhkan sesuai dengan kriteria yang telah ditetapkan dengan menggunakan metode Simple Additive Weighting (SAW).

\subsection{Sistem Pendukung Keputusan}

Sistem pendukung keputusan menurut (Ariyanti, dkk 2015) adalah sekumpulan prosedur berbasis model untuk data pemrosesan dan penilaian guna membantu para manajer mengambil keputusan. Sistem pendukung keputusan (Decision Support System) dirancang untuk memberikan informasi yang dapat membantu proses pengambilan keputusan dan kemampuan komunikasi untuk menjawab problem semi-terstruktur. 


\subsection{Metode Simple Additive Weighting}

Metode SAW sering dikenal dengan istilah metode penjumlahan terbobot. Konsep dasar metode SAW adalah mencari penjumlahan terbobot dari rating kinerja pada setiap alternatif pada semua atribut. Metode SAW dapat membantu dalam pengambilan keputusan suatu kasus, akan tetapi perhitungan dengan menggunakan metode SAW ini hanya yang menghasilkan nilai terbesar yang akan terpilih sebagai alternatif yang terbaik (Djamain \& Christin, 2015). Perhitungan akan sesuai dengan metode ini apabila alternatif yang terpilih memenuhi kriteria yang telah ditentukan. Metode SAW ini lebih efisien karena waktu yang dibutuhkan dalam perhitungan lebih singkat (Djamain \& Christin, 2015).

Adapun rumus dari perhitungan metode SAW adalah sebagai berikut :

$$
r i j\left\{\begin{array}{l}
\frac{X i j}{M a x X i j} \\
\frac{M i n x i j}{x i j}
\end{array} \quad\right. \text { jika j adalah atribut keuntungan (benefit) }
$$

jika j adalah atribut biaya (cost)

Dimana :

$$
\begin{aligned}
& \text { Rij = nilai rating kinerja ternormalisasi } \\
& \text { Xij = nilai atribut yang dimiliki dari setiap kriteria } \\
& \text { Max xij = nilai terbesar dari setiap kriteria } \mathrm{i} \\
& \text { Min xij = nilai terkecil dari setiap kriteria } \mathrm{i} \\
& \text { Benefit = jika nilai terbesar adalah terbaik } \\
& \text { Cost = jika nilai terkecil adalah terbaik }
\end{aligned}
$$

\section{Metode Penelitian}

Subyek penelitian yang dilakukan dalam penelitian ini adalah bagin HRD dan karyawan di RS PKU Muhammadiyah Yogyakarta. Pada penelitian ini akan dilakukan dengan metode Simple Additive Weighting (SAW). Pengumpulan data merupakan usaha yang dilakukan untuk memperoleh data-data yang relevan terhadap bahasan dalam penelitian ini. Data yang diperoleh kemudian diproses sesuai dengan kebutuhan pengembangan produk dan penyusunan laporan. Adapun metodemetode pengumpulan data yang digunakan adalah sebagai berikut :
a. Metode Studi Literatur
b. Metode Observasi
c. Metode Wawancara

\section{Hasil dan Pembahasan}

\subsection{Tahap Analisis}

Analisis dalam tahap ini termasuk penentuan pendekatan yang dilakukan, tidak ada cara tertentu yang dapat diikuti untuk mengadakan analisa, sehingga setiap peneliti harus mempunyai metode perancangannya tersendiri yang dirasakan sesuai dan cocok dengan saat penelitian. Adapun kebutuhan sistem yang digunakan membangun sistem ini antara lain :

1. Input (data masukan)

Data pengguna digunakan untuk menginputkan data pengguna. Data pengguna berisikan data tim seleksi (admin) yang bertugas sebagai admin yang mengelola sistem. Admin bisa mengakses semuanya, sedangkan pimpinan dan calon karyawan hanya bisa mengakses hasil 
seleksi keputusan dan laporan. Dalam sistem ini yang bertugas sebagai admin adalah bagian HRD.

2. Kebutuhan Proses

Adapun kebutuhan proses yang terdapat dalam sistem ini adalah sebagai berikut :

a. Sistem mampu menyimpan dan memproses data calon karyawan, data kriteria, data subkriteria, data nilai dan data pengguna.

b. Mampu melakukan perhitungan dengan metode SAW.

c. Mampu menampilkan hasil seleksi yang layak dan diterima sebagai calon karyawan baru sesuai kriteria yang telah ditentukan.

d. Mampu memberikan laporan hasil seleksi yang telah dihitung.

3. Output (data keluaran)

Keluaran yang dihasilkan dari sistem ini adalah sebuah alternatif yang memiliki nilai tertinggi dibandingkan nilai alternatif lainnya. Hasil alternatif yang diambil dari urutan alternatif tertinggi ke alternatif terendah. Alternatif yang dimaksud adalah calon karyawan. Adapun hasil dari sistem ini antara lain:

a. Menampilkan data calon karyawan.

b. Menampilkan hasil akhir dari seleksi calon karyawan baru.

Program seleksi karyawan baru ini memiliki alur keputusan yang berjalan sesuai dengan sistem yang ada. Alur keputusan metode SAW bisa dilihat pada gambar 1 .

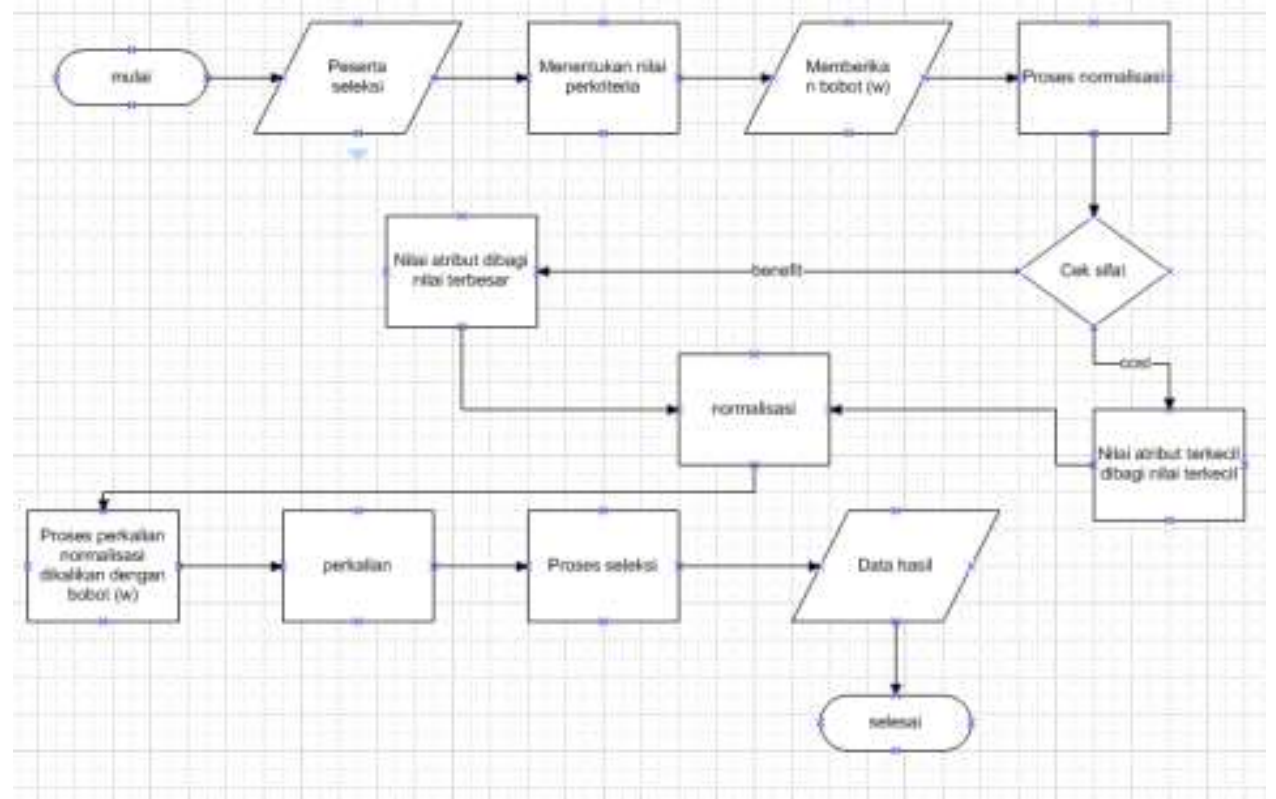

Gambar 1. Alur Keputusan

\subsection{Tahap Implementasi}

a. Form Tampilan Kriteria

Merupakan form yang digunakan untuk menginputkan nama kriteria, tipe kriteria, dan juga terdapat menu edit kriteria dan hapus kriteria. Adapun tampilan gambar form kriteria bisa dilihat pada gambar 2 . 


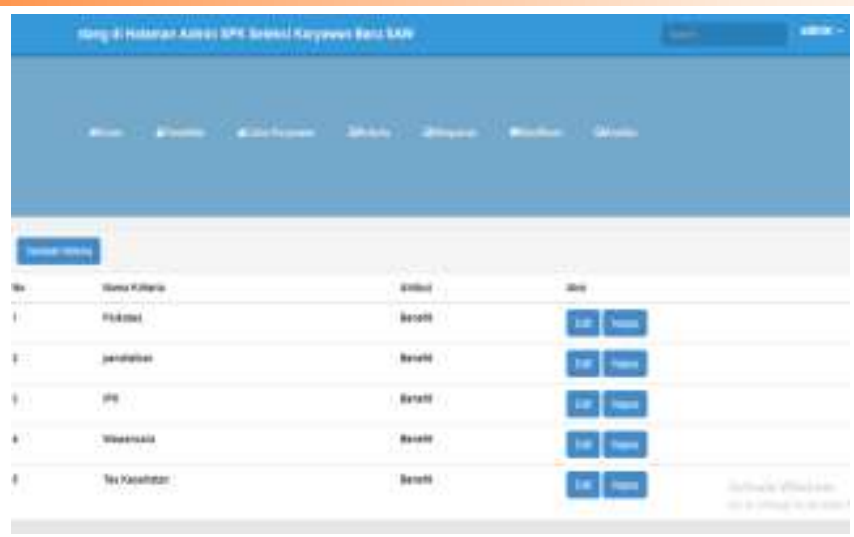

Gambar 2 . Form Tampilan Kriteria

b. Form Tampilan Subkriteria

Merupakan form untuk menginputkan nama kriteria, nama subkriteria, nilai, dan juga keterangan dan dapat diubah ataupun dihapus. Adapun form subkriteria bisa dilihat pada gambar 3 .

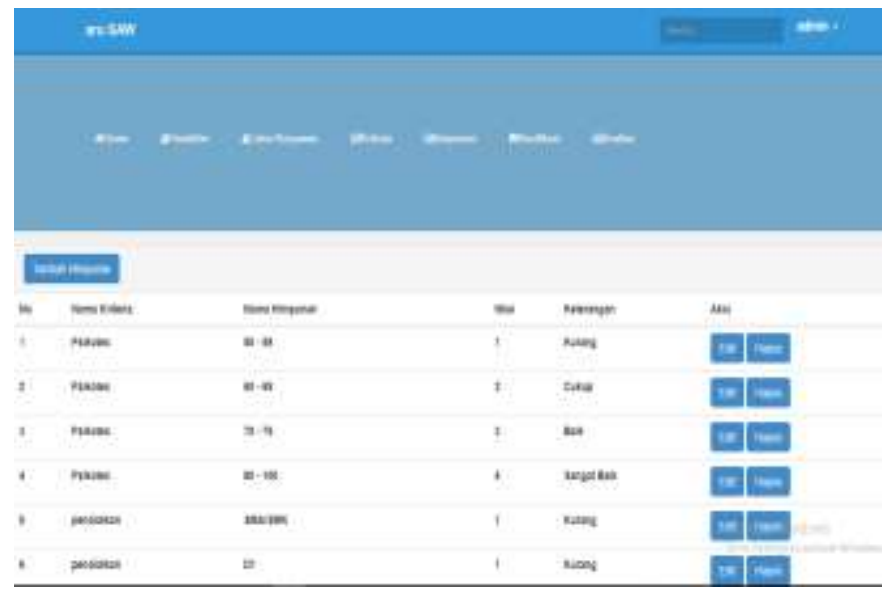

Gambar 3. Form Tampilan Subkriteria

c. Form Tampilan Penilaian Calon Karyawan

Form ini digunakan untuk menampilkan nama pelamar, nilai bobot himpunan. Dalam form ini terdapat menu menambahkan calon karyawan dan memilih nilai dari setiap subkriteria. Adapun form penilaian calon karyawan bisa dilihat pada gambar 4 .

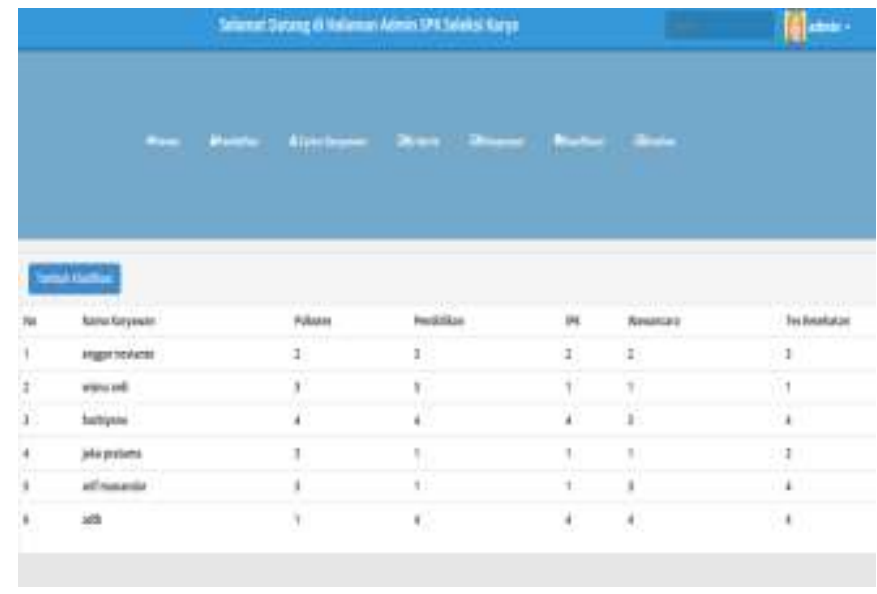

Gambar 4. Form Penilaian Calon Karyawan 
d. Form Tampilan Hasil Analisa Metode SAW

Form analisa menampilkan nama pelamar, nilai bobot dari setiap kriteria, normalisasi, dan perangkingan, yang akan menjadi pertimbangan oleh pihak HRD dalam menentukan calon karyawan yang memiliki kriteria baik dan sesuai yang telah di tetapkan. Adapun form tampilan hasil analisa bisa dilihat pada gambar 5 .

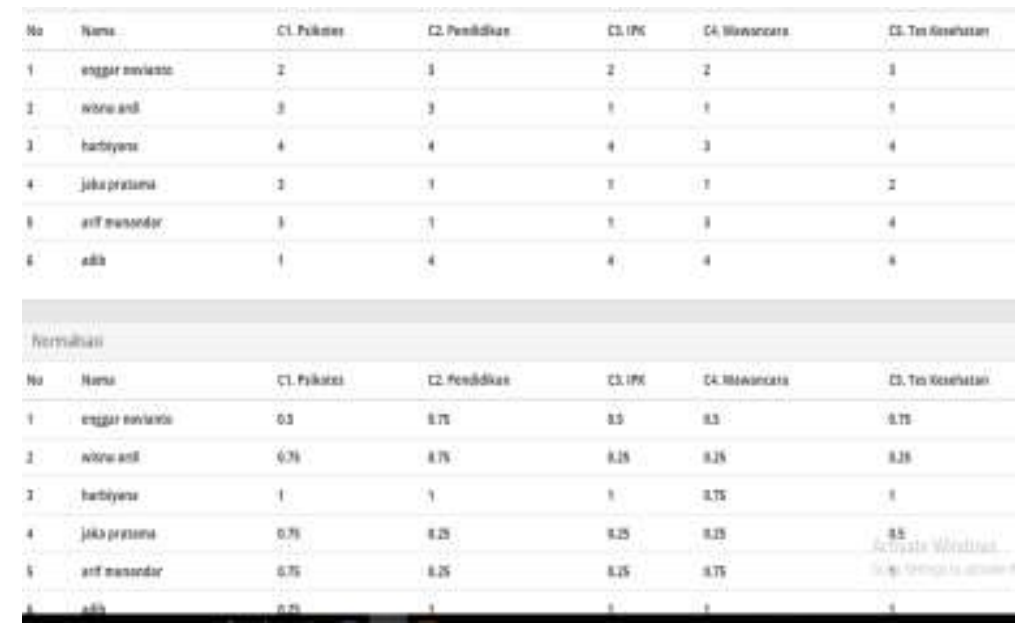

Gambar 5. Form Hasil Analisa Metode SAW

\section{Kesimpulan dan Saran}

\subsection{Kesimpulan}

Dari hasil uraian pada bab-bab sebelumnya dan memperhatikan aplikasi Sistem Pendukung Keputusan Seleksi Calon Karyawan Dengan Metode SAW, maka dapat disimpulkan sebagai berikut:

1. Telah dibuat aplikasi sistem pendukung keputusan seleksi calon karyawan untuk menentukan calon karyawan yang memiliki nilai terbaik dari setiap kriteria yang telah ditentukan.

2. Aplikasi ini akan digunakan kepada pengguna yaitu bagian HRD untuk membantu proses perekrutan calon karyawan.

3. Metode SAW secara valid $100 \%$ dapat diterapkan dalam penilaian kinerja calon karyawan di RS PKU Muhammadiyah Yogyakarta.

\subsection{Saran}

Aplikasi ini dapat dikembangkan lagi dengan penambahan fitur lainnya, seperti hasil rekomendasi posisi dan dikembangkan lagi dengan menggunakan aplikasi berbasis android yang jika digunakan lebih efisien dan bisa digunakan dimana saja dan kapan saja.

\section{Daftar Pustaka}

Ariyanti, D. M., Agus, F., \& Khairina, D. M. (2015). Penerimaan Dan Penentuan Posisi Karyawan, 10(1), 62-64.

Djamain, Y., \& Christin, H. De. (2015). Sistem Pendukung Keputusan Penerimaan Pegawai Baru Pt.Pln (Persero) Kantor Pusat Dengan Menggunakan Metode Simple Additive Weighting (Saw), 8(1), 39-47.

Imbar, R. V., \& Hartanto, B. S. (N.D.). Aplikasi Sistem Informasi Sumber Daya Manusia Dengan Fitur DSS Menggunakan Metode Topsis Pada PT . X, 125-144. 
Jannah, R. (n.d.). Aplikasi Penerimaan Karyawan dengan Metode Multi Attribute Utility Theory Riadhil Jannah.

Nurul Azizah \& Sri Winiarti. 2014. Sistem Pendukung Keputusan Seleksi Calon Karyawan Dengan Metode Promethee Studi Kasus Pamella Group Yogyakarta. Jurnal Sarjana Teknik Informatika, Volume, No 1

Tegal, S. Y. M. I. (2016). Perancangan Sistem Pendukung Keputusan Seleksi Penerimaan Pegawai Menggunakan Metode SAW Pada PDAM Tirta Dharma Tegal, 3(2).

Verina, W., Andrian, Y., \& Rahmad, I. F. (2015). Penerapan Metode Fuzzy SAW Untuk Penerimaan Pegawai Baru (Studi Kasus STMIK Potensi Utama). Jurnal Ilmiah SISFOTENIKA, $5(\mathrm{X}), 60-70$ 